\title{
Attractiveness Factors Influencing Shoppers' Satisfaction, Loyalty, and Word of Mouth: An Empirical Investigation of Saudi Arabia Shopping Malls
}

\author{
Ala'Eddin Mohammad Khalaf Ahmad \\ Assistant Professor of Marketing, Faculty of Economics and Administration \\ King Abdulaziz University, Jeddah, Kingdom of Saudi Arabia \\ Tel: 966-56-852-7444 E-mail: amahmed1@kau.edu.sa; aladdin.a.h@hotmail.com
}

Received: September 7, 2012

Accepted: October 8, $2012 \quad$ Online Published: November 9, 2012

doi:10.5430/ijba.v3n6p101

URL: http://dx.doi.org/10.5430/ijba.v3n6p101

\begin{abstract}
The purpose of this research is to investigate the attractiveness factors influencing shoppers' satisfaction, loyalty, and word of mouth in Saudi shopping mall centers. The independent variables were attractiveness factors represented by these variables namely aesthetic, convenience and accessibility, product variety, entertainment, and service quality. The dependent variables were shopper satisfaction, loyalty and WOM. A structured questionnaire was distributed to a sample of 600 shopping mall customers, representing all of the shopping malls shoppers in the city of Jeddah, Saudi Arabia. A purposive sampling technique was employed in this research. The multiple regression analysis showed the impact of shopping malls attractiveness factors on the shopper satisfaction. The attractiveness factors aesthetic, convenience and accessibility, product variety, entertainment, and service quality, had a positive effect on Saudi shopping mall shoppers'. The most significant factor was product variety. This research potentially contributes to shopping malls attractiveness factors and their impact on shoppers' satisfaction in shopping malls of Saudi Arabia.
\end{abstract}

Keywords: Shopping malls, Attractiveness factors, Shopper satisfaction, Loyalty, WOM, KSA

\section{Introduction}

The last decade has witnessed an accelerating and significant raise in Saudi Arabia retail sector. Saudi residents and tourism can clearly viewer a dramatic growing movement in the establishment of shopping malls all over the Kingdom, specifically in the main cities.

There are many crucial factors which translated to change in shopping malls patterns from traditional shopping markets to the more modern one stop shopping centers. These factors are increasing the economic wealth, prosperity, shifting lifestyle, cultural differences among the residents and visitors, ethnic mix, and addition to hot weather and humidity (El-Adly, 2001).

Authors who have addressed multi facets of the gravitational pull model include: Hise and Muczyk (1977) impact of highways on drive time; McGoldrick and Thompson (1992) time, distance, and accessibility; Barnard and Hensher (1992) and Kitamura et al (1998) travel time; Dennis et al (2001) transportation mode dimensions; and Gautschi (1981) and Ibrahim (2002) center-related dimensions like assortment, hours of operation and travel-related dimensions, including comfort, cost, and safety concerns. Also many scholars have addressed shopping malls behavior from the viewpoint of consumer's perception of store image include: Bearden (1977) who examined downtown vs. outlying shopping center patronage characteristics, Wakefield and Baker (1998); Dennis et al (2002); Boatwright and Nunes (2001) who distinguished product variety concept in shopping malls. Finn and Louviere (1996) who studied the impact of anchor stores; and Bone and Ellen, (1999); Yavas (2003); Fiore et al, (2000); Mattila and Wirtz, (2001); Ward et al, (2003) who studied the impact of merchandizing, accessibility, services, and atmospherics on patronage. Talpade and Hayes (1997); Frasquest et al, study (2001); and Sit et al, (2003) who discussed the entertainment in shopping mall and its contribution in customer satisfaction. Zeithaml et al, (2006); Baker et al, (2002); Cronin and Taylor, (1992); Lee et al, (2000); Kang and James, (2004) who studied the impact of service quality on customer satisfaction. 
Many empirical studies found that there is a positive and significant relationship between attractiveness factors and shoppers' satisfaction in shopping malls. Therefore, the purpose of this research is to determine the attractiveness factors of shopping malls from the shoppers' perspective and its impact on shopper satisfaction, loyalty, and positive WOM.

\section{Literature Review}

\subsection{Attractiveness Factors Influencing Shopper Satisfaction}

\subsubsection{Aesthetic}

The influence of the servicescape on consumer behavior, decision making, and service evaluations has been studied primarily in retail environments (Turley and Milliman, 2000; Zeithaml et al, 2006). The effects of ambient factors such as music, smell, and lighting have been of particular interest to consumer researchers, as these characteristics can be experimentally manipulated to test for cause-and-effect relationships (Ezeh and Harris, 2007).

Kwortnik and Ross (2007) define an experiential product as "fusing tangible (sensory) and intangible (symbolic) attributes and co-produced by consumer and marketer to create an event that is pleasurable, meaningful, and memorable". For experiential products, a well-designed servicescape establishes the context in which the service is performed (Bitner, 1992; Pullman and Gross, 2004).

Five common atmospheric items measured are ambience, color, décor, music and layout (Bell, 1999; Frasquet et al, 2001). Atmospherics are critical because they act as environmental cues that consumers use to imply the quality of a shopping centre (Smith and Burns, 1996). Further, atmospherics have been reported to stimulate consumer excitement at a shopping mall (Wakefield and Baker, 1998).

Baker et al, (2002) parsimonious ambient, design, and social factors capture the exterior, general interior, store layout, interior displays, and human stimulus variables proposed by Turley and Milliman (2000) the ambient, space/function, and signs/symbols/artifacts variables proposed by Bitner (1992).

The ambient factor includes non-structural elements of the retail environment (e.g. music, scent, and lighting). The variables studied differ by ambient cue. For instance, pertinent aspects of scent include congruity with other cues (Carman, 1990; Cronin and Taylor, 1992; Bone and Ellen, 1999; Pegler, 1999; Lee et al, 2000; Fiore et al, 2000; Mattila and Wirtz, 2001; Baker et al, 2002; Kang and James, 2004; Schifferstein and Blok, 2002; Zeithaml, 2006); Pleasantness (Knasko, 1995; Fiore et al, 2000; Mattila and Wirtz, 2001). Therefore, it is hypothesized that:

Ha1: Aesthetics have a positive and significant effect on shopper satisfaction.

\subsubsection{Convenience and Accessibility}

Accessibility can be further divided into macro-accessibility and micro-accessibility. Macro-accessibility concerns access road conditions to the centre and the proximity of the centre from the customer's place of work or residence. Contrasting macro-accessibility, micro-accessibility refers to parking facilities within the centre and ease of navigation within the shopping centre (Finn and Louviere, 1996; Bell, 1999; Frasquet et al, 2001).

Bodkin and Lord (1997) concluded that the most important reasons for selecting malls were convenience, presence of a specific store in the mall, services and prices.

The term one-stop shopping implies that all but the most esoteric of shopping needs can be satisfied in the one centre, all at the one time (Kaufman, 1996). Because consumers are increasingly undertaking multi-purpose shopping trips (Arentze et al, 2005), they are likely to favor centers that offer one-stop shopping.

The demand for extended trading hours derives from the emergence of a 24-hours society. The increased fragmentation of working hours has changed consumer perceptions of what people should do and when. In such a climate, competing based on time becomes all-important (Richbell and Kite, 2007).

Anselmsson (2006) found that convenience (comprising trading hours) served as the third most important influence over satisfaction and the fifth largest influence over mall-visit frequency. Hence, trading hours appear to exert a salient influence over patronage behavior. However, there are doubts as to whether they serve as an important attribute for all shoppers.

Dennis et al, (2005) studied the attributes that influence retail spending and found enclosure to be one of the five most important determinants. However, more typical of the confused nature of the debate Kim et al (2005), found that despite the fact that a majority of respondents indicated that the weather affected their patronage behavior, 76 per cent still indicated they prefer an outdoor shopping area. Therefore, it is hypothesized that: 
Ha2: convenience and accessibility have a positive and significant effect on shopper satisfaction.

\subsubsection{Product Variety}

The concept of "branding" is well known in consumer products, Dennis et al (2002) demonstrated that techniques of brand image measurement can be used for malls and can help towards customer satisfaction and commercial success for shopping malls (Dennis et al, 2001).

Brand extension is defined as a "use of established brand names to enter new product categories or classes" (Keller and Aaker, 1992). According to the American Marketing Association (2008), brand extension also means "a product line extension marketed under the same general brand as a previous item or items".

Boatwright and Nunes (2001) suggest that consumer preferences are affected by the perception of variety within a selection, which in turn depends on more than just the number of distinct products on the shelves. Therefore, it is hypothesized that:

Ha3: product variety has a positive and significant effect on shopper satisfaction.

\subsubsection{Entertainment}

Bloch et al, (1994) examined the effect of mall physical environment on consumers' emotional states and found that malls were viewed by consumers as a place not only for shopping, but also for other activities, such as entertainment.

In the same line, Nicholls et al (2002) found that today's mall patrons tend to be more leisure driven than shoppers in the early 1990s. Wakefield and Baker (1998) found that the mall environment influences the desire to stay and re-patronage intentions to the mall. Other studies (Finn and Louviere, 1996; Sit et al, 2003) have pointed out the importance of the shopping centre image as a critical determinant of consumer patronage decisions. Frasquest et al, (2001), found that two entertainment items, namely "events, exhibitions, and attractive leisure offer", were associated with the "atmosphere/leisure" attribute. There are two possible explanations for entertainment being associated with different attributes. First, there could have been a temporal shift in the role of entertainment at a shopping centre, initially from being part of the augmented product (service) to becoming part of the core product (variety/assortment), and to being considered an environmental cue (atmosphere). Second, consumers are not homogeneous, and thus they may perceive a similar entertainment item differently in terms of their meanings and importance. Sit et al, (2003) found that "entertainment is pivotal to shopping centers because it induces an exciting and fun shopping experience, which in turn could entice consumer patronage" (Sit et al, 2003). In other words, different studies reflect different consumer groups who attribute different meaning to "entertainment". Therefore, it is hypothesized that:

Ha4: entertainment has a positive and significant effect on shopper satisfaction.

\subsubsection{Services Quality}

Previous research has offered some evidence that service quality perceptions significantly influence purchase intentions. For example, Parasuraman et al $(1985,1991)$ have found a positive relationship between consumers' perceptions of service quality and their willingness to buy. A study using mall intercepts, by Taylor et al, (1997), investigated the relative roles of quality perceptions in the formation of purchase intentions of Mexican consumers. Taylor et al, (1997) found that service quality perceptions contribute to purchase intentions. Boulding et al, (1993) also uncovered a significant correlation between service quality and behavioral intentions.

The functional quality (how) is defined as "how the technical quality is transferred to the customer. It is the way in which a service quality is being delivered to the customer (the functional or process quality dimension" (Gronroos, 1990). The five SERVQUAL dimensions developed by Parasuraman et al, (1985) were modified to measure functional quality. Modification of the instrument for different service settings is encouraged by the original developers of the instrument (Parasuraman et al, 1991) and other researchers (e.g., Carman, 1990; Cronin and Taylor, 1992; Lee et al., 2000; Kang and James, 2004) employed the SERVQUAL as an adequate measure for functional quality.

The technical quality dimension is defined as the outcome of the service production process interaction in which the resources are used (the technical or outcome quality of the process) e.g., the use of a safe deposit box in a bank. Since there have been few measures developed to assess the technical quality of banking services from managers' perspectives, in-depth interviews with managers were conducted to generate items to assess technical quality. In addition, previous work was also consulted to develop technical quality items (Gronroos, 1984; Kang and James, 2004). Therefore, it is hypothesized that:

Ha5: service quality has a positive and significant effect on shopper satisfaction. 


\subsection{Shoppers' Satisfaction}

Some researchers like (Cronin and Taylor, 1992) have argued that satisfaction is a transaction-specific measure. Other researcher' view satisfaction as an overall evaluation that is based on the total purchase consumption and experience (Anderson et al, 1994). In general, satisfaction has been conceptualized in terms of whether the product/service meets consumer needs and expectations (Zeithaml et al, 2006). Oliver (1997, p.28), who defined satisfaction as "the summary psychological state resulting when the emotion surrounding disconfirmed expectations is coupled with a prior feelings about the consumer experience".

In the direction, satisfaction has been defined as "the consumer's fulfillment response, which is a judgment that a product or service feature, or the product or service itself, provided a pleasurable level of consumption related fulfillment, including levels of under or over fulfillment" (Oliver, 1997, p. 13). Satisfaction has been found to significantly affect consumer's attitude, retention behavior and loyalty to the stores and services. It is a vital outcome of marketing activity that leads to revisiting stores, repeat product purchases, and word-of-mouth promotion to friends (Singh, 1990; Bloemer and Lemmink, 1992; Anderson et al, 1994; Tanner, 1996; Zeithaml et al, 1996). Therefore, it is hypothesized that:

Ha6: Shoppers' satisfaction has a positive and significant effect on shopper Loyalty.

Ha7: Shoppers' satisfaction has a positive and significant effect on shopper positive WOM.

\subsection{Shoppers' Loyalty}

Loyal customers are reported to have higher retention rates, commit a higher share of their category spending to the firm and to be more likely to recommend the firm to other potential customers (Kotler et al, 2010). Oliver (1999, p. 34) defines loyalty as "a deeply held commitment to re-buy or repatronize a preferred product/service consistently in the future, thereby causing repetitive same brand or same brand-set purchasing, despite situational influences and marketing efforts having the potential to cause switching behavior". Broadly, loyalty development has been an objective traditionally aimed at by managers (Andreassen, 1999) since it enables higher future purchase intention. In particular, loyalty may be defined as a customer's intention or predisposition to purchase from the same organization again (Edvardsson et al, 2000), that result from the conviction that the value received from one seller is greater than the value available from other alternatives (Hallowell, 1996). As a consequence, loyalty has been considered to be a key factor in order to achieve organization success and sustainability over time (Keating et al, 2003), and several authors have proposed that loyalty also favors higher intensity in positive WOM (Hallowell, 1996), lower price sensibility (Lynch and Ariely, 2000) and more stable and bigger incomes (Knox and Denison, 2000). Therefore, it is hypothesized that:

Ha8: Shopper loyalty has a positive and significant effect on shopper positive WOM.

\subsection{Shoppers' WOM}

Word-of-mouth (WOM) is comfortable and informal mode of communication between personal parties concerning the evaluation of goods and services (Singh, 1990). Marketing literature has consistently shown its role in influencing consumers' attitudes. For example, WOM is found to have more influence on product judgments than less vivid printed information (Herr et al, 1991).

In general, WOM may be defined as an informal type of communication between private parties concerning the evaluation of goods and services and it has been considered to be one of the most powerful forces in the market place (Bansal and Voyer, 2000). The importance of WOM resides in the fact that consumer choice is usually influenced by WOM, especially when the purchase in important. This appears due to consumers prefer to rely on informal and personal communication sources in making purchase decisions instead of on formal and organizational sources such as advertising campaigns (Bansal and Voyer, 2000).

\section{Rationale for Research}

This paper attempts to fill a gap in the subject of attractiveness factors in shopping malls in KSA. The study addressed some of the shortcomings in the literature such as looking at the attractiveness factors from the point of view of aesthetics, convenience and accessibility, product variety, entertainment, and service quality, to investigating the influences attractiveness factors on loyalty and positive WOM in the Saudi shopping malls. It was established that no previous research had been conducted at Saudi shopping malls, that investigated the relationship between the attractiveness factors and the outcomes of satisfaction namely loyalty and positive WOM in the Saudi shopping malls. 


\section{Research Objectives}

Based on the relevant literature of the attractiveness of shopping centers, shoppers' satisfaction, loyalty, and WOM, the research objectives are:

1) To establish and define the attractiveness factors of the shopping malls in KSA.

2) To examine the effect of attractiveness factors on shoppers' satisfaction.

3) To examine the effect of shoppers' satisfaction on outcomes of satisfaction namely (loyalty and WOM).

\section{Research Methodology}

\subsection{Population and Sample}

The current research population represents all the 24 shopping malls that are operating in Jeddah city in KSA and are registered with the (Ministry of Commerce and Industry, 2011; Jeddah Chamber of Commerce and Industry, 2011).

The research population consisted of all the shoppers who visit at any of these shopping malls. Therefore, all the shopping malls shoppers were called and invited to participate in the research survey. The researcher was distributed 600 research questionnaires were gathered 550 questionnaires, yielding a response rate of $91.6 \%$. These questionnaires were fully and correctly completed. Respondents typically held purposive sample.

Every questionnaire was personally handed and instructions were given to each shopper's before completing the questionnaire. In terms of demographic findings, (70.4\%) of respondents were males, and the remaining (29.6\%) were females. In terms of the age group of respondents, it is interested to note that (27.4\%) of them are less than (26) years, whereas (29.1\%) fell into the (26-30) age group, whereas (15.1\%) fell into the (31-35) age group, whereas $(12.3 \%)$ fell into the (36-40) age group, whereas (8.4\%) fell into the (41-45) age group, only (7.8\%) are above this group. As for the educational levels of those customers, around the half $(48.9 \%)$ were secondary school degree holders, and parallel percentage (45.1\%) of these, have bachelor degree, and the rest percentage were represented the postgraduate holders (6\%) See table (1).

\subsection{Data Collection}

The research questionnaire was designed based on previous empirical literature. The questionnaire design was pre-tested and redesigned through personal interviews with shopping malls mangers and shops and outlets owners in these shopping malls.

The research questionnaire was used as primary data collection method as shown in (Table 2,3). The components of attractiveness factors as independent variables and shoppers satisfaction, loyalty, and WOM as dependent variables items were measured on 5-point Likert- scale ranging from 5 (strongly agree) to 1 (strongly disagree). For the all

dimensions, the research respondents were asked to indicate the degree of agreement or disagreement on the attractiveness factors items that shopping malls used and pay attention in order to achieve shoppers' satisfaction. For the outcomes of satisfaction, the respondents were asked to indicate how important they believed of shoppers' satisfaction.

Multiple items were used to assess their measurement properties. Consistent with the literature, the scale items selected for the dependent variable were direct measures of shoppers' satisfaction with influences received from attractiveness factors as independent variables. This format has been recommended for marketing surveys.

Both the independent and dependent variable(s) deployed in the research are explained in Table 2 and 3 according to the proposed hypotheses.

\section{Results and Discussion}

The basic assumptions of this research are that attractiveness factors namely (aesthetic, convenience and accessibility, product variety, entertainment, and service quality) influencing shoppers satisfaction, loyalty, and word of mouth. The current research was used a multiple regression modeling approach which proposed as an effective method for studying the relationships between the research variables. As shown in Table 4, the adjusted R2 is 0.521 , suggesting that the five attractiveness factors clarify close to 52 per cent of the variance for the dimension of satisfaction. Particularly, other tables also take action variables have a statistically significant outcome on satisfaction. Of these significant variables, product variety, aesthetic, and convenience and accessibility come out to have the most influence on satisfaction.

Moreover, it expected that the influence of such factors (aesthetic, convenience and accessibility, product variety, entertainment, and service quality) on satisfaction would vary according to the personal variables, which are personal 
characteristics (as shown in table 4). The results of the multiple regression analysis signal that there is variation in the effect of attractiveness factors on satisfaction and empirical evidence in this research suggests that attractiveness factors have a significant degree of influence on satisfaction and outcomes of satisfaction. This empirical evidence has provided significant support for the attractiveness factors in shopping malls literature.

The outcomes empirically verify that attractiveness factors play an essential role in the satisfaction among shoppers in Saudi shopping malls.

\subsection{The Attractiveness Factors Have a Positive Significant Influence on Shoppers' Satisfaction}

Practically, the model assumed that attractiveness factors positively influence shopper satisfaction in the Saudi shopping malls. In addition, it predicted that the influence of such factors on shopper satisfaction would differ according to the personal variable that is gender, age, and education level. marital status (table 4). The results of the multiple regression analysis signal that there is variation in the effect attractiveness factors on shoppers' satisfaction. The current research suggests that attractiveness factors have a significant degree of influence on shoppers' satisfaction. This empirical evidence has provided significant support for the attractiveness and shopping malls literatures, which substantively advocate that attractiveness factors have an influence on shopper satisfaction (Bitner, 1992; Pullman, 2004; Kim et al, 2005; Richbell and Kite, 2007; Kwortnik and Ross, 2007; Ezeh and Harris, 2007).

\subsection{Aesthetic Has a Positive Significant Influence on Shoppers' Satisfaction}

Aesthetic is also considered to be one of the influential factors on the satisfaction of shopper in Saudi shopping malls (Table 4). Prior research has empirically found positive relationship between aesthetic and shopper satisfaction as critical factors on the shopping (Bitner, 1992; Pullman, 2004; Kwortnik and Ross, 2007; Ezeh and Harris, 2007).

These results are expected as when Saudi shopping malls owners consider the aesthetic as a competitive tool; this might impact positively on the pay attention to shopping malls facilities and visuals to increase the demand of these centers. Consequently, the current research able to confirm that aesthetic has a significant influence on shopper satisfaction. These findings are also consistent with other research findings. For example, (Bitner, 1992; Pullman, 2004; Kwortnik and Ross, 2007; Ezeh and Harris, 2007) found that aesthetic provides higher degree of enjoyment that facilitates shoppers to shopping in Saudi shopping malls.

\subsection{Convenience and Accessibility Have a Positive Significant Influence on Shoppers' Satisfaction}

Examining data appears that a precondition for increasing the demand and visits of shoppers is that the location, opening hours, and other convenient factors have leading to a win-win situation. Factors such as convenience and accessibility should help to build effective relationships and increase the shopper satisfaction in the current and long run times.

Convenience is important dimension that may affect shopper intention to increase the value of these shopping malls. Convenience and accessibility consider as one of the most influential factor on shopper satisfaction as shown in table (4). These findings are also consistent with other research findings. For example, (Dennis et al, 2005; Kim et al, 2005; Richbell and Kite, 2007).

\subsection{Product Variety Has a Positive Significant Influence on Shoppers' Satisfaction}

The findings in table (4) provide significant support for the variety literature which advocates that variety of products have an influence upon Saudi shopping malls. As a result, the current research is able to validate that variety has a significant influence on shoppers' satisfaction. These findings are also consistent with other research findings (Boatwright and Nunes, 2001; Dennis, 2002).

\subsection{Entertainment Has a Positive Significant Influence on Shoppers' Satisfaction}

Entertainment is also considered to be one of the influential factors on the satisfaction of Saudi shoppers (Table 4). Previous research has investigational found positive relationship between entertainment facilities and shopper satisfaction as critical factors on the shopping (Bloch et al, 1994; Finn and Louviere, 1996; Frasquest, 2001; Sit et al, 2003).

These results indicate that the entertainment is an important element to facilitate the shopping activities which is reflects on the shoppers' satisfaction. Other researchers have empirically found positive relationship between entertainment and shopper satisfaction as critical factors during shopping (Finn and Louviere, 1996; Frasquest, 2001; Sit et al, 2003). 


\subsection{Service Quality Has a Positive Significant Influence on Shopper Satisfaction}

An examination of table (4) suggests that service quality is an influential factor on shopper satisfaction in Saudi shopping malls. The results consequently, verify that service quality has a positive behavior on shopper satisfaction. These findings are also consistent with other research findings. For example, (Taylor, 1997; Parasuraman et al, 1991; Lee et al, 2000; Kang and James, 2004) found that service quality provides higher degree of satisfaction that enables shoppers' to trust shopping at all times.

In abstract, it can be seen that all attractiveness factors, which aesthetic, convenience and accessibility, product variety, entertainment, and service quality, have proven to positively shopper satisfaction.

Examining data in tables $(5,6)$ it show that shoppers' satisfaction has a positive significant influence on shoppers' loyalty of activating attractiveness factors by Saudi shopping malls. This result wide spreads on the other research results (loyalty on positive WOM and also customer satisfaction on positive WOM).

Loyalty and WOM were clarified at an alike level in the proposed model (R2 loyalty $=0.421$, R2 SAT influence WOM=0.411). In general speaking, the current research can conclude that satisfaction is a key mediating factor in the loyalty and positive WOM in the attractiveness factors in Saudi shopping malls.

\section{Implications}

The hypothetical foundation of this research is based on literature from the attractiveness factors relating to shoppers satisfaction within the shopping malls in KSA. With the growing number of modern shopping malls in Jeddah city in $\mathrm{KSA}$, it is obvious that competition in this service industry is increasing dramatically. Mall operators should be recognized of the needs and wants of the targeted shoppers' to build and maintain a profitable relationship.

The empirical conclusions drawn from this research are multifaceted and as a result, it is vitally important that shopping mall owners and managers pay attention to the influences of shopper satisfaction. Researchers are therefore encouraged to place more focus on the impact influences stemming from the attractiveness and motivation factors and its impact on shopper satisfaction within Saudi shopping malls.

\section{Conclusions}

This research seeks to make an original contribution to knowledge by investigating the impact of attractiveness factors on shopper satisfaction and outcomes shopper loyalty and shopper positive WOM in the shopping malls industry in KSA. This research contributes to the services marketing discipline in finding out the role of the attractiveness factors namely (aesthetic, convenience and accessibility, product variety, entertainment, and service quality) in enhancing shopper satisfaction, loyalty, and positive WOM.

Factors related to aesthetic, convenience and accessibility, product variety, entertainment, and service quality were a spotlight of this research as they have an influence on shopper satisfaction.

Contributions found will be valuable for both academics and managers in a similar way. Academically, this effort aims to spotlight academic interest upon a much neglected field - the marketing of shopping malls in KSA. There is at present a distinctive lack of studies in academia relating to research in the Gulf countries and Middle East Region.

This is fairly astounding when considering that KSA has been at the head of the shopping malls industry in the Gulf Countries and Middle East Region.

The shopping malls industry is a vital and energetic sector in KSA because of many reasons one of these reasons is the warm weather in the majority of KSA cities and the searched city-Jeddah in particular. Although this research has provided valuable insights into a somewhat scant area of research, it has been subject to some limitations. To begin with, there were some difficulties in the distribution of the research questionnaire within the customers of Saudi shopping malls, possibly leading to some inconsistencies in the data collection process. For example, a portion of shopping malls opted to distribute the instrument to respondents themselves, where in other cases the researcher delivered the survey to respondents individually. In addition, this research has been conducted within a single service industry and exclusively in the Saudi shopping malls sector, thus limiting the generalisability of the research results to the foreign or Gulf countries.

As noted findings should consider broader directions for future research. First, the research should be simulated with other region and cities in KSA or other Gulf countries to further examine the attractiveness factors in the other industry. Second, studying the proposed model in service sector for examples spa villages, or hotels in order to gain more validation for the model and more generalized findings. Thirdly, Future research should also investigate 
whether the model could be used for different dependent variables e.g. market share or profits. Finally, studying more attractiveness factors normally influence the shopper satisfaction to gather more information on this issue.

\section{References}

Ahmad, A., Al-Zu'bi, H. (2011). E-banking Functionality and Outcomes of Customer Satisfaction: An Empirical Investigation. International Journal of Marketing Studies, 3(1), 50-65.

Anderson, W., Fornell, C., \& Lehmann, R. (1994). Customer satisfaction, market share, and profitability: findings from Sweden. Journal of Marketing, 58, 53-66. http://dx.doi.org/10.2307/1252310

Andreassen, W. (1999). What drives customer loyalty with complaint resolution? Journal of Service Research, 1(4), 324-32. http://dx.doi.org/10.1177/109467059914004

Anselmsson, J. (2006). Sources of customer satisfaction with shopping malls: a comparative study of different customer segments. International Review of Retail, Distribution and Consumer Research, 16(1), 115-138. http://dx.doi.org/10.1080/09593960500453641

Arentze, A., Oppewal, H., \& Timmermans, H. (2005). A multi-purpose shopping trip model to assess retail agglomeration effects. Journal of Marketing Research, 42(1), 109-129. http://dx.doi.org/10.1509/jmkr.42.1.109.56884

Baker, J., Parasuraman, D., Grewal, D., \& Voss, G.B. (2002). The influence of multiple store environment cues on perceived merchandise value and patronage intentions. Journal of Marketing, 66(2), 120-141. http://dx.doi.org/10.1509/jmkg.66.2.120.18470

Bansal, S., \& Voyer, A. (2000). Word of mouth processes within a services purchase decision context. Journal of Service Research, 3(2), 166-177. http://dx.doi.org/10.1177/109467050032005

Barnard, O., \& Hensher, A. (1992). The spatial distribution of retail expenditure. Journal of Transport Economics and Expenditure, 26(3), 299-312.

Bearden, W. (1977). Determinant attributes of store patronage - downtown versus outlying shopping centers. Journal of Retailing, 53(2), 15-22.

Bell, S. (1999). Image and consumer attraction to intraurban retail areas: an environmental psychology approach. Journal of Retailing and Consumer Services, 6, 67-78. http://dx.doi.org/10.1016/S0969-6989(98)00015-0

Bitner, J. (1992). Servicescapes: the impact of physical surroundings on customers and employees. Journal of Marketing, 56, 57-71. http://dx.doi.org/10.2307/1252042

Bloch, H., Ridgway, M., \& Dawson, A. (1994). The consumer mall as shopping habitat. Journal of Retailing, 23-42. http://dx.doi.org/10.1016/0022-4359(94)90026-4

Bloemer, M., \& Lemmink, B. (1992). The importance of customer satisfaction in explaining brand and dealer loyalty. Journal of Marketing Management, 8(4), 351-64. http://dx.doi.org/10.1080/0267257X.1992.9964204

Boatwright, P., \& Nunes, J. (2001, July). Reducing assortment: An attribute-based approach. Journal of Marketing, 65, 50-63. http://dx.doi.org/10.1509/jmkg.65.3.50.18330

Bodkin, C., \& Lord, J. (1997). Attraction of power shopping centres. The International Review of Retail, Distribution \& Consumer Research, 7(2), 93-108. http://dx.doi.org/10.1080/095939697343058

Bone, F., \& Ellen, S. (1999). Scent in the marketplace: explaining a fraction of olfaction. Journal of Retailing, 74(2), 169-191.

Boulding, W., Kalra, A., Staelin, R., \& Zeithaml, V. (1993, February). A dynamic process model of service quality: from expectations to behavioral intentions. Journal of Marketing Research, 30, 7-27. http://dx.doi.org/10.2307/3172510

Carman, J. M. (1990). Consumer perceptions of service quality: An assessment of the SERVQUAL dimensions. Journal of Retailing, 66(1), 33-55

Cronin Jr, J., \& Taylor, A. (1992, July). Measuring service quality: a reexamination and extension. Journal of Marketing, 56, 55-68. http://dx.doi.org/10.2307/1252296

Dennis, E., Murphy, J., Marsland, D., Cockett, W., \& Patel, T. (2002). Measuring image: mall case studies. International Review of Retail, Distribution and Consumer Research, 12(4), 353-373. http://dx.doi.org/10.1080/09593960210151153 
Dennis, C., Marsland, D., \& Cockett, T. (2001). Data mining for shopping centres - customer knowledge-management framework. Journal of Knowledge Management, 5(4), 368-374. http://dx.doi.org/10.1108/13673270110411797

Dennis, C., Newman, A., \& Marsland, D. (2005). Objects of Desire: Consumer Behavior in Shopping Centre Choices. Palgrave, London.

Edvardsson, B., Johnson, D., Gustafsson, A., \& Strandvik, T. (2000). The effects of satisfaction and loyalty on profits and growth: products versus services. Total Quality Management, 11, 917-927. http://dx.doi.org/10.1080/09544120050135461

El-Adly, M. (2007). Shopping malls attractiveness: a segmentation approach. International Journal of Retail \& Distribution Management, 35(11), 936-950. http://dx.doi.org/10.1108/09590550710828245

Ezeh, C., \& Harris, C. (2007). Servicescape research: a review and a research agenda, The Marketing Review, 7(1), 59-78.

Finn, A., \& Louviere, J. (1996). Shopping center image, consideration, and choice: anchor store contribution. Journal of Business Research, 35, 241-51. http://dx.doi.org/10.1016/0148-2963(95)00129-8

Fiore, M., Yah, X., \& Yoh, E. (2000). Effects of a product display and environmental fragrancing on approach responses and pleasurable experiences. Psychology \& Marketing, 17, 27-54. http://dx.doi.org/10.1002/(SICI)1520-6793(200001)17:1<27::AID-MAR3>3.0.CO;2-C

Frasquet, M., Gil, I., \& Molla, A. (2001). Shopping-centre selection modelling: a segmentation approach. International Review of Retail, Distribution and Consumer Research, 11(1), 23-38.

Gautschi, D. (1981). Specification of patronage models for retail center choice. Journal of Marketing Research, 18, 162-74. http://dx.doi.org/10.2307/3150951

Grönroos, C. (1984). A service quality model and its marketing implications. European Journal of Marketing, 18(4), 36-44. http://dx.doi.org/10.2307/3150951

Grönroos, C. (1990). Service Management and Marketing: Managing the Moments of Truth in Service Competition. Lexington Books, Lexington, MA.

Hallowell, R. (1996). The relationships of customer satisfaction, customer loyalty, and profitability: an empirical study. International Journal of Service Industry Management, 7(4), 27-42. http://dx.doi.org/10.1108/09564239610129931

Herr, M., Kardes, R., \& Kim, J. (1991). Effects of word of mouth and product-attribute information on persuasion: an accessibility-diagnosticity perspective. Journal of Consumer Research, 17(3), 454-62. http://dx.doi.org/10.1086/208570

Hise, R., \& Muczyk, J. (1977). The effect of interstate highway on driving time and regional shopping center drawing power. Journal of the Academy of Marketing Science, 5(2), 126-34. http://dx.doi.org/10.1007/BF02722006

Ibrahim, M. (2002). Disaggregating the travel components in shopping centre choice. Journal of Property Investment \& Finance, 20(2), 277-294. http://dx.doi.org/10.1007/BF02722006

Jeddah Chamber of Commerce and Industry. (2011). Annual Report, Jeddah-Kingdom of Saudi Arabia.

Kang, G., \& James, J. (2004). Service quality dimensions: an examination of Gro"nroos's service quality model. Managing Service Quality, 14(4), 266-277. http://dx.doi.org/10.1108/09604520410546806

Kaufman, F. (1996). A new look at one-stop shopping: a TIMES model approach to matching store hours and shopper schedules. Journal of Consumer Marketing, 13(1), 4-52. http://dx.doi.org/10.1108/07363769610147848

Keating, B., Rugimbana, R., \& Quazi, A. (2003). Differentiating between service quality and relationship quality in cyberspace. Managing Service Quality, 13(3), 217-232. http://dx.doi.org/10.1108/07363769610147848

Keller, L., \& Aaker, D. (1992). The Effects of Sequential Introduction of Brand Extensions. Journal of Marketing Research, 29(February), 35-50. http://dx.doi.org/10.2307/3172491

Kim, I., Christiansen, T., Feinberg, R., \& Choi, H. (2005). Mall entertainment and shopping behaviors: a graphical modeling approach. Advances in Consumer Research, 32(1), 487-492.

Kitamura, R., \& Fujii, S. (1998). Two computational process models of activity-travel behavior. In T. Garling, T. Laitila and K. Westin (Eds.), Theoretical Foundations of Travel Choice Modeling (pp. 251-279). 
Knasko, C. (1995). Pleasant odors and congruency: effects on approach behavior. Chemical Senses, 20, 479-487. http://dx.doi.org/10.1093/chemse/20.5.479

Knox, D., \& Denison, J. (2000). Store loyalty: its impact on retail revenue. An empirical study of purchasing behaviour in the UK. Journal of Retailing and Consumer Services, 7(1), 33-45. http://dx.doi.org/10.1016/S0969-6989(98)00033-2

Kotler, P., Armstrong, G., \& Tolba, A. (2011). Principles of Marketing- Arab World Edition. Pearson.

Kwortnik, R., \& William, R. (2007). The Role of Positive Emotions in experiential decisions. International Journal of Research in Marketing, 24(4), 324-335. http://dx.doi.org/10.1016/j.ijresmar.2007.09.002

Lee, H., Lee, Y., \& Yoo, D. (2000). The determinants of perceived service quality and its relationship with satisfaction. Journal of Services Marketing Research, 14(2/3), 217-32. http://dx.doi.org/10.1108/08876040010327220

Lee, S., Ahn, G., zhang, X., \& Campbell, A. (2000). INSIGNIA: An IP-Based Quality of Service Framework for Mobile ad Hoc Networks. Journal of Parallel and Distributed Computing, 60(4), 374-406. http://dx.doi.org/10.1006/jpdc.1999.1613

Lynch, J., \& Ariely, D. (2000). Wine Online: Search Costs Affect Competition on Price, Quality and Distribution. Marketing Science, 19(1), 83-103. http://dx.doi.org/10.1287/mksc.19.1.83.15183

Mattila, S., \& Wirtz, J. (2001). Congruency of scent and music as a driver of in-store evaluations and behavior. Journal of Retailing, 77(2), 273-89. http://dx.doi.org/10.1016/S0022-4359(01)00042-2

McGoldrick, J., \& Thompson, G. (1992). Regional Shopping Centres. Avebury, Aldershot.

Ministry of Commerce and Industry. (2011), Annual Reports, Riyadh, Kingdom of Saudi Arabia.

Nicholls, J., Li, F., Kranendonk, C., \& Roslow, S. (2002). The seven year itch? Mall shoppers across time. Journal of Consumer Marketing, 19(2), 149-65. http://dx.doi.org/10.1108/07363760210420568

Oliver, R. L. (1997). Satisfaction: A Behavioral Perspective on the Consumer. McGraw-Hill, Boston, MA.

Oliver, L. (1999). Whence customer loyalty? Journal of Marketing, 63, 33-44. http://dx.doi.org/10.2307/1252099

Parasuraman, A., Berry, L., \& Zeithaml, V. (1991). Refinement and reassessment of the SERVQUAL scale. Journal of Retailing, 67(Winter), 420-450.

Parasuraman, A., Zeithaml, A., \& Berry, L. (1985). A conceptual model of service quality and its implications for future research. Journal of Marketing, 49(Fall), 41-50. http://dx.doi.org/10.2307/1251430

Pegler, M. (1999). Retail Entertainment, Retail Reporting Corporation. New York, NY.

Pullman, E., \& Gross, J. (2004). Ability of experience design elements to elicit emotions and loyalty behaviors. Decision Sciences, 35, 551-578. http://dx.doi.org/10.1111/j.0011-7315.2004.02611.x

Richbell, S., \& Kite, V. (2007). Night shoppers in the 'open 24 hours' supermarket: a profile. International Journal of Retail \& Distribution Management, 35(1), 54-68. http://dx.doi.org/10.1108/09590550710722341

Schifferstein, H., \& Blok, S. (2002). The Signal Function of Thematically (In) congruent Ambient Scents in a Retail Environment. International Journal of Retail \& Distribution Management, 27, 539-549.

Singh, J. (1990). Voice, exit, and negative word-of mouth behaviors: an investigation across three service categories. Journal of the Academy of Marketing Science, 18(1), 1-15. http://dx.doi.org/10.1007/BF02729758

Sit, J., Merriless, B., \& Birch, D. (2003). Entertainment-seeking shopping centre patrons: the missing segments. Journal of Retail \& Distribution Management, 31(2), 80-94. http://dx.doi.org/10.1108/09590550310461985

Smith, P., \& Burns, D. (1996). Atmospherics and retail environments: the case of the power aisle. International Journal of Retail \& Distribution Management, 24(1), 7-14. http://dx.doi.org/10.1108/09590559610107076

Talpade, S., \& Hayes, J. (1997). Consumer shopping behavior in malls with large scale entertainment centers. Mid-Atlantic Journal of Business, 33(2), 153-162.

Tanner, F. (1996). Buyer perceptions of the purchase process and its effect on customer satisfaction. Industrial Marketing Management, 25(2), 125-133. http://dx.doi.org/10.1016/0019-8501(95)00071-2

Taylor, A., Nicholson, D., Milan, J., \& Martinez, V. (1997). Assessing the roles of service quality and customer satisfaction in the formation of the purchase intentions of Mexican consumers. Journal of Marketing Theory and Practice, 5(1), 78-92. 
Turley, W., \& Milliman, E. (2000). Atmospheric effects on shopping behavior: A Review of the Experimental Evidence. Journal of Business Research, 49(2), 193-211. http://dx.doi.org/10.1016/S0148-2963(99)00010-7

Wakefield, L., \& Baker, J. (1998). Excitement at the mall: determinants and effects on shopping response. Journal of Retailing, 74(4), 515-39. http://dx.doi.org/10.1016/S0022-4359(99)80106-7

Ward, D., \& Kerfoot, S. (2003). Visual merchandising and the creation of discernible retail brands. International Journal of Retail \& Distribution Management, 31(3), 143-152. http://dx.doi.org/10.1108/09590550310465521

Yavas, U. (2003). A multi-attribute approach to understanding shopper segments? Journal of Retail \& Distribution Management, 31(11), 541-548. http://dx.doi.org/10.1108/09590550310465521

Zeithaml, V., Bitner, J., \& Gremler, D. (2006). Services Marketing. New York: McGraw-Hill.

Zeithaml, V., Berry, L., \& Parasuraman, A. (1996). The behavioral consequences of service quality. Journal of Marketing, 60(2), 31-46. http://dx.doi.org/10.2307/1251929

Table 1. Demographic data

\begin{tabular}{lc}
\hline \multicolumn{1}{c}{ Characteristics } & $\%$ \\
\hline 1.1 Age & 27.4 \\
Under 26 & 29.1 \\
$26-30$ & 15.1 \\
$31-35$ & 12.3 \\
$36-40$ & 8.4 \\
$41-45$ & 7.8 \\
over 45 & \\
\hline 1.2 Gender & 70.4 \\
Male & 29.6 \\
Female & \\
\hline 1.3 Educational Level & 48.9 \\
Secondary School & 45.1 \\
Bachelor's degree & 6 \\
Postgraduate & \\
\hline
\end{tabular}

Table 2. Attractiveness factors (aesthetic, convenience and accessibility, product variety, entertainment, and service quality): independent variables

\section{Aesthetic (independent variable)}

The interior design of the malls usually attracts my attentions; I notice the color of the mall interior, The environment (i.e. lighting and decoration) in the malls attracts my attentions, I am usually in a good mood when I am in mall, It's a fun place to walk around, It's a clean place, It has interesting architectural features

\section{Convenience and Accessibility (independent variable)}

I visit the mall because of its convenient location to my house, I visit the mall because it is easier to find a parking space at economy rate, The mall store hours are convenient, Mall is a one-stop shopping place, This shopping mall is located near my work, Finding the products I am looking for is easy in this shopping mall, Easy access to product information, All the products and brands you were expecting to buy were available.

\section{Product Variety (independent variable)}

The style of the products in this shopping mall is outdated, The style of the products in this shopping mall is up to date, The quality of the products available in this shopping mall is high, I feel good shopping at department stores that carry not only their "private label brands", The mall sell good quality brands, Plurality and variety of restaurants, Availability of int'l stores branches, Existence of large food court, Presence of cinemas in the mall. 


\section{Entertainment (independent variable)}

The mall has playing area suitable for children, The mall has safe entertainment place, Presence of fun and variety entertainment programs , Existence of fun spaces for kids, The mall has entertainment places for youth

\section{Service Quality (independent variable)}

In this shopping mall, the sales people are helpful. In this shopping mall, the sales people are polite, The quality of this shopping mall's service is excellent, The staff at the mall were welcoming, I received good advice from the salespeople, You were satisfied with the answer to a complaint you had lodged.

Table 3. Shopper satisfaction: dependent variable

\section{Shoppers' Satisfaction (independent variable)}

I think that I made the correct decision to use this mall. The experience that I have had with this mall has been satisfactory, In general terms, I am satisfied with the way that this mall has carried out shopping, In general, I am satisfied with the service I have received from the mall.

\section{Shoppers' Loyalty (independent variable)}

I have the intention to continue my relationship with this shopping mall, Based on my experience, I'm very likely continuing my relationship with this shopping mall in the nexttime.

\section{WOM (independent variable)}

I will recommend this shopping mall to other shoppers'; I will point out the positive aspects of this shopping mall if anybody criticizes it.

Table 4. Results -attractiveness factors (shoppers' Satisfaction)

\begin{tabular}{|c|c|c|c|c|c|}
\hline $\begin{array}{c}\text { Attractiveness } \\
\text { Factors }\end{array}$ & B & Standardized error & Beta & t-value & Significant \\
\hline $\begin{array}{l}\text { Attractiveness } \\
\text { Factors }\end{array}$ & 0.762 & 0.231 & 0.563 & 3.299 & 0.000 \\
\hline Aesthetic & 0.812 & 0.347 & 0.309 & 3.646 & 0.001 \\
\hline $\begin{array}{c}\text { Convenience and } \\
\text { Accessibility }\end{array}$ & 0.766 & 0.321 & 0.302 & 3.762 & 0.001 \\
\hline Product Variety & 0.785 & 0.267 & 0.288 & 3.155 & 0.003 \\
\hline Entertainment & 0.542 & 0.239 & 0.311 & 2.876 & 0.050 \\
\hline Service Quality & 0.650 & 0.402 & 0.381 & 2.871 & 0.012 \\
\hline
\end{tabular}

Note: R 2 = 0.631; Adjusted R 2 =0.521; F =17.630; P $<0.05$.

Table 5. Results -shoppers' satisfaction (shoppers' loyalty)

\begin{tabular}{llclll}
\hline Shoppers' Satisfaction & B & Standardized error & Beta & t-value & Significant \\
\hline Shoppers' Satisfaction & 0.522 & 0.277 & 0.322 & 3.066 & 0.010 \\
\hline
\end{tabular}

Note: $\mathrm{R} 2=0.481$; Adjusted R 2 = 0.421; $\mathrm{F}=8.710 ; \mathrm{P}<0.05$.

Table 6. Results -Loyalty (WOM)

\begin{tabular}{llllll}
\hline IM & B & Standardized error & Beta & t-value & Significant \\
\hline IM & 0.543 & 0.281 & 0.268 & 3.271 & 0.001 \\
\hline
\end{tabular}

Note: R 2 = 0.431; Adjusted R 2 = 0.401; F =8.220; P $<0.05$ 